\title{
Collective Action in Communities Exposed to Recurring Hazards: The Camp Fire, Butte County, California, November 8, 2018
}

\author{
L.K. Comfort ${ }^{\mathrm{a},}{ }^{*}$, K. Soga ${ }^{\mathrm{b}}$, M. McElwee ${ }^{\mathrm{c}}$, C. Ecosse $^{\mathrm{b}}$, B. Zhao ${ }^{\mathrm{b}}$ \\ ${ }^{a}$ CITRIS, Policy Lab, ${ }^{b}$ Department of Civil and Environmental Engineering \\ University of California, Berkeley, Berkeley, CA 94720, United States \\ ${ }^{c}$ Associate, Exponent, 475 14th Street, Suite 400, Oakland, CA 94612, United States \\ Corresponding author: "lcomfort@berkeley.edu
}

\begin{abstract}
Wildfires constitute an increased risk for California, with the frequency, size, and scale of extreme events and ensuing losses escalating year by year. This article presents a case study of the Camp Fire, Butte County, California, on November 8, 2018. The event exceeded the parameters of prior emergency planning and led to the loss of 85 lives, the deadliest wildfire in California's history. The study's objective is to identify gaps in the information flow within and among actors that led to this outcome and to propose more robust strategies that would enable communities to manage wildfire risk sustainably. Data were collected through documentary analysis of existing emergency plans, policies, and protocols; field site visits to the damaged area; attendance at the Paradise Town meeting; and semi-structured interviews with emergency officials who had responsibility for managing the event and residents of the damaged area. A unique combination of highly risky conditions compelled the urgent evacuation of the entire Town of Paradise when emergency personnel was committed to fire suppression in a neighboring community, leaving residents of Paradise to manage their evacuation. Communications failed; regional communities, not alerted, continued standard traffic patterns, creating a massive slowdown in evacuation from Paradise. Key insights from this study include: 1) the need to model wildfire as a regional event; 2) informed residents of communities at risk act collectively to protect the community as a whole; and 3) interaction of science, technology, and human organizations create an interdisciplinary science for managing wildfire.
\end{abstract}

Keywords - Wildfire; evacuation plans; communications technologies; traffic modeling; community resilience.

Manuscript received 20 Jan. 2021; revised 27 Mar. 2021; accepted 5 May 2021. Date of publication 31 Aug. 2021. IJASEIT is licensed under a Creative Commons Attribution-Share Alike 4.0 International License.

\section{INTRODUCTION}

California faces a continuing crisis. As environmental conditions increase the frequency and severity of wildfires and populations move into areas prone to wildfires, social and economic losses escalate exponentially [1]. California now experiences wildfire events throughout the year, and the risk is spreading nationally, increasing in the western states of Washington, Oregon, Arizona, and Colorado and the southeastern states of Florida and Alabama as well. The total economic cost of the 2017 California wildfires alone was estimated at $\$ 18$ billion, with the ensuing social costs of interrupted schooling, housing, transportation, business operations adding time and trauma to the recovery [2]. The insured losses of the 2018 wildfires in California tallied at more than $\$ 12$ billion [3]. These escalating costs are unsustainable. Determining new models for how communities can identify and reduce the risk of wildfires is essential for the millions of residents - men, women, children -- who live at the urban/wildland interface. Building the capacity for collective action to reduce this massively complex problem is a task that only the whole region can solve.

\section{MATERIALS AND METHOD}

The Camp Fire, November 8, 2018, represents an instructive case study [4] of the size, scale, and costs of wildfire risk in California. This article summarizes the findings from a Quick Response study of the Camp Fire, conducted with support from the National Science Foundation administered through the Natural Hazards Center, University of Colorado, Boulder [5]. The interdisciplinary research team from the University of California, Berkeley included three faculty researchers and four graduate students in engineering, public policy, architecture, and computational modeling. The research team collectively made six field trips to the firedamaged region to interview decision-makers at federal, state, 
county, city, and town organizations who were actively engaged in response and recovery operations for the fire. The research team also reviewed news reports, agency documents, official emergency plans, and documented visual observations of the damaged area.

This analysis undertakes five tasks. It will first briefly characterize the wildfire risk to the Town of Paradise and Butte County and review the responsible organizations' organizational plans and preparedness actions prior to the event. Second, it will present a preliminary timeline of the event, documenting the severity of the actual event against plans and resources available. Third, the analysis assesses the dynamic conditions and processes that shaped actual performance during this event. Fourth, it presents a model of traffic simulation as an example of exploratory research to design alternative strategies for managing evacuation on a regional scale in future wildfire or hazardous events. Finally, the analysis concludes with possible strategies for mitigating wildfire risk in a changing ecological, economic, and social climate.

\section{RESULTS AND DISCUSSION}

\section{A. The 2018 Camp Fire: Context and Measures Taken to Reduce Wildfire Risk}

The ferocity of the Camp Fire can only be understood by setting the event in the context of the physical geography, terrain, and climate of the region. The Town of Paradise is aptly named, nestled in a pine forest, bounded by a canyon with the Sierra Nevada mountains rising behind the town and the Sacramento Valley stretching below. Yet, this idyllic location is uniquely susceptible to wildfire, as summers get longer and hotter, parched pine needles fall from the trees, and winds blow fiercely through the Jarbo Gap, the canyon that separates the ridge on which the town is built and the mountains behind. Any ignition can be deadly.

Responsible officials and townspeople in Paradise are well aware of the risk of wildfire. Cal Fire, California's state agency responsible for fire detection, prevention, and preparedness, had organized training exercises based on wildfire hazards in the region for twenty years. Butte County had experienced wildfire events previously, most recently in 2008. County and town officials had used these events to review the risk and develop detailed plans for preparedness and evacuation. The Town of Paradise had developed a detailed plan for evacuation of residents, identifying 14 zones specifying the order in which residents would evacuate, to allow time for the 26,682 residents to leave safely over the four routes out of town (Cal Fire, Unit 35, 2018). All residents were counseled to know their zone and the order of zones for evacuation, if necessary. Pamphlets were distributed to households to inform them of the Ready, Set, Go program for evacuation. The Town Council scheduled town meetings to engage residents in developing individual and neighborhood evacuation strategies. Emergency services personnel conducted simulated evacuation exercises using the contraflow strategy to allow residents to practice driving on all four lanes of the highway out of town (Professional interview, Oroville, CA, 03/26/2019).

Yet, an unusual confluence of events on November 8 , 2018 , overwhelmed the plans and protocols enacted to protect the region and enable the residents of Paradise and the surrounding towns and cities to manage the risk of wildfire. Importantly, the network of formal plans and policies for wildfire risk reduction developed by the State of California, Butte County, and the Town of Paradise provide evidence of the investment of time, thought, and effort that had been made to counter the risk. Essentially, three major types of planning activities undergirded the response operations for this extreme event. First, the set of federal frameworks for emergency planning developed by the Federal Emergency Management Agency (FEMA) outline a common set of goals and emergency support functions for all fifty states in the United States (U.S.). These frameworks represent a formal set of organized plans that structure emergency support functions for all types of hazards. The frameworks were developed at the federal level but are intended to structure and coordinate response operations across all jurisdictional levels - federal, state, county, city, and town -- for the nation. The five frameworks include: Prevention, Protection, Mitigation, Response, and Recovery [6]. Consistent with the federal frameworks, each jurisdiction develops its own emergency plan to reflect the specific hazards and resources that characterize its hazard- scape [7], [8]. The State of California, subject to a range of natural hazards - earthquakes, wildfire, floods, landslides, and drought - has developed the Standardized Emergency Management System (SEMS) to ensure a common set of terms, functions, and operations procedures across the 58 counties and their component municipalities [9].

This inter-jurisdictional network of emergency plans provides a common framework for operations and training in emergency events that exceed the resources and capacity of a single jurisdiction and require collaboration and shared response operations across multiple jurisdictions. Similarly, Butte County has developed its county-wide plan that outlines procedures and resources available to monitor and manage risk within its geographic and environmental boundaries. The Town of Paradise, within Butte County, developed an emergency plan with a focus on wildfire, recognizing the geological/meteorological/climate-related risks to the community [10].

The second type of planning activities focused on developing the communications infrastructure, protocols, and procedures for detecting and reporting emergency incidents and mobilizing prompt response operations to bring incidents under control as quickly and efficiently as possible. Central to achieving effective coordination in rapidly escalating emergencies, communication is dependent on the technical infrastructure that enables it. Although California has a statewide 911 system through which emergency calls can be made by telephone from any location in the state, calls are routed through a Voice-over-Internet-Protocol (VoIP) system to a Public Safety Access Point (PSAP) closest to the site of the reported incident. There are 437 PSAPs state-wide in California, which provide a comprehensive network of local access points. Calls received at the PSAPs are then transmitted over commercial telephone services or agency radio channels to local jurisdictions and agencies to mobilize response operations. In extreme events, commercial telephone services are vulnerable to disruption from hazards if cell towers are damaged or transmission lines are downed. 
Agency radio systems have cross-over channels between some agencies, not all. Even so, in a rapidly developing event, access to a shared radio channel, for example, between Police and Fire agencies, can become difficult, as many personnel attempts to communicate messages at once (Professional interview, 01/15/2019). Alternatively, if a critical agency does not share a radio channel and the commercial phone systems are down, it becomes extremely difficult to coordinate actions under urgent conditions [11]. Organizational coordination is constrained by the technical infrastructure that enables it.

The third set of activities central to building the capacity of a community to respond collectively to an extreme event is the informal development of a sense of shared community and informed commitment to reduce risk. These activities are often set by the example of local leadership in articulating a clear vision of risk for the whole community and outlining a set of actions that all residents can take to reduce that risk. For example, the Town Council in Paradise held town meetings to engage residents in developing and reviewing the evacuation plans for the town. The Butte County Sheriff's Office organized a "Truck or Treat" event for Hallowe'en in 2018 and invited community residents to bring their children, dressed in costume, to visit the Office, meet the personnel, and see the equipment and vehicles that help to keep the community safe (Professional interview, Oroville, $03 / 26 / 2019)$. These informal interactions between public agencies and community residents in non-emergency times forge a bond of trust among residents and between residents and public officials crucial in enabling community residents to act collectively in uncertain situations. This bond rests upon an awareness of shared risk and a clear understanding of credible actions that can be taken to reduce that risk for the whole community. A list of organizational partners and other organizations that contributed to response operations in the Camp Fire is included in Appendix A.

\section{B. Preliminary Timeline and Critical Decision Points in Response Operations}

An abbreviated timeline of critical points of decision is shown in Figure 1. The times and events listed were cited in interviews by participants in the events but are not taken from official records. We requested the 209 incident status reports for the Camp Fire that Cal Fire maintained, but we were informed that those reports would not be available until the investigation was closed since the case was under investigation. When the 209 incident reports are available, we will request them to do a more systematic analysis of the time, direction, and interaction among agencies documented by inter-agency communications and model possible alternative strategies under different conditions of time, access, and types of equipment.

The rapid progression of events that characterized the Camp Fire in Butte County, California, represented an extraordinary alignment of physical, meteorological, and ecological conditions that overwhelmed the capacity of the network of organizations that had anticipated and planned for an extreme wildfire event. As the timeline in Figure 1 below shows, the fire, ignited by sparks from a faulty transmission tower managed by the utility company that provides electrical power to Northern California, Pacific Gas \& Electric Company, started spot fires in the forested area near Pulga, an unincorporated community on the west side of the Feather River Canyon [12].

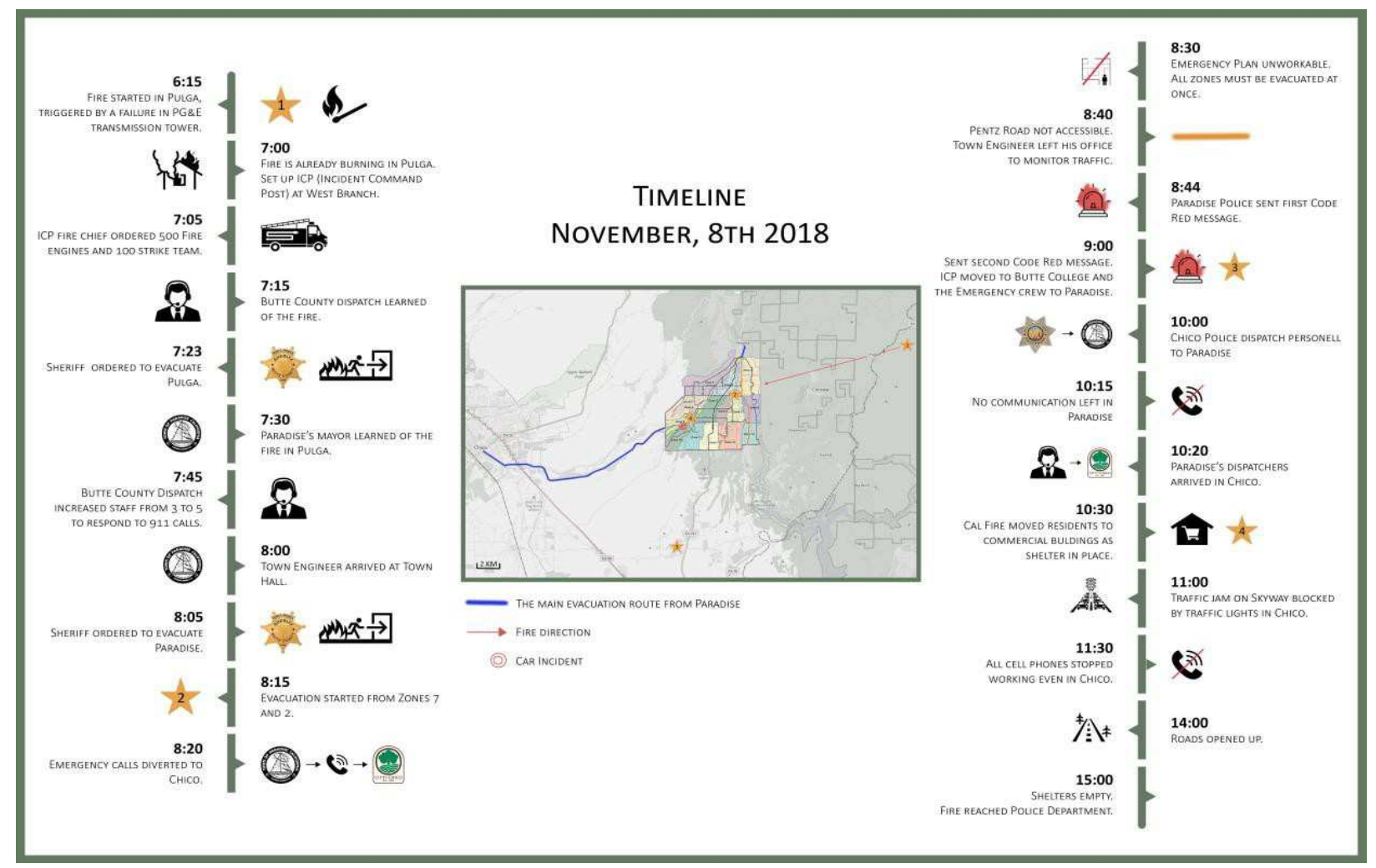

Fig. 1 Timeline of critical events showing the progression of the Camp Fire, Butte County, November 8, 2019 
Emergency crews initially set up an Incident Command Post at West Branch near Pulga to contain the fire, but hot, dry winds picked up embers, and within an hour, carried them across the canyon to threaten the Town of Paradise, some 20 miles away by direct flight. In Paradise, ecological conditions, including 237 days without rain and a beetle infestation in its pine forest, had left the town dangerously vulnerable to wildfire, with dead timber and dry pine needles providing ready fuel for the flames. These conditions proved far more complex and dynamic than anticipated by the deliberate planning process or that the physical conditions could overcome.

Wildfire is a known risk in Butte County, and residents of the region had experienced a major wildfire in 2008. The question is how to reduce that risk under changing conditions. The local Fire Department in Paradise, Unit 35, Butte County, operates within the larger network of Cal Fire, the state-wide fire protection agency, and developed a detailed plan for evacuation of residents by zone in case of fire [10]. The Paradise Town Council held town meetings to introduce the plan to town residents, and engage them in evacuation exercises, given the limited number of routes out of town. The townspeople had practiced 'contraflow,' driving in one direction out of town; Paradise earned the reputation as a 'firesafe community'(Professional interview, Feb. 12, 2019).

Figure 2 shows the map of Paradise with the 14 designated evacuation zones and four routes out of town. Zones 2 and 7 were designated as the zones to evacuate first, using Pentz Road to Oroville. Pentz Road, closest to Feather River Canyon, was quickly engulfed in flames and rendered inaccessible. As the fire spread, Clark Road became inaccessible, leaving only two viable routes out of town. All efforts by emergency personnel and townspeople focused on evacuation. As the fire advanced through Paradise, the townspeople recognized the extreme risk and moved quickly to rescue themselves and their neighbors, acting collectively to help each other. Although 85 lives were lost in this deadly fire, $99 \%$ of the population of Paradise evacuated safely in a remarkable display of self-organizing collective action for the benefit of the whole community.

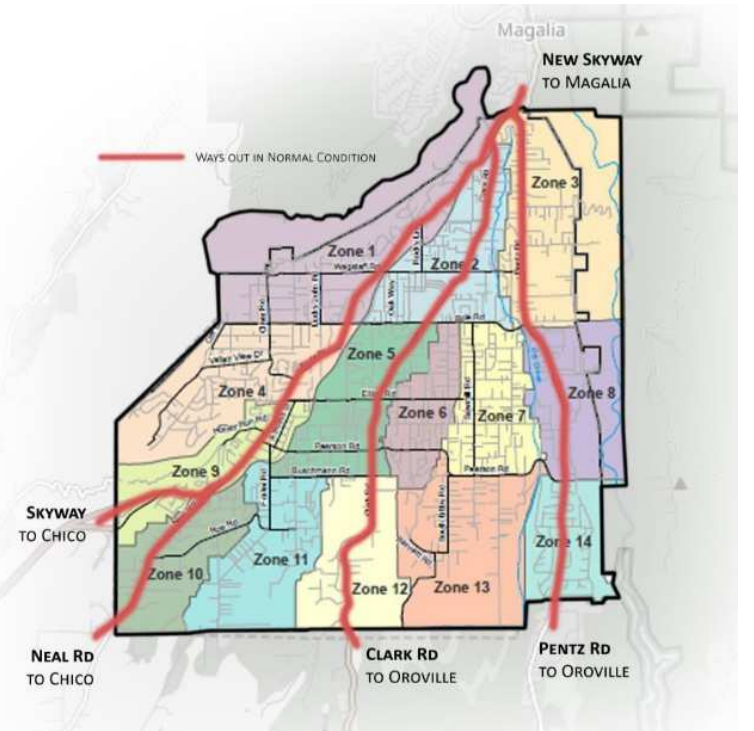

Fig. 2 Map of Paradise showing evacuation zones and routes out of town.

\section{The Dynamics of Wildfire}

The central question echoing through this study is how did a spot fire ignited by a relatively modest electrical spark in wildlands escalate so quickly into the catastrophic fire that devastated Paradise and burned 153,336 acres of wildlands, communities, and forest in Butte County? What dynamic interactions among natural, physical, ecological, technical, and human conditions triggered and amplified this event [13]? What innovations or insights gained from this event would reduce risk in future scenarios as human communities move increasingly into wildland areas [14]? Four areas warrant special attention, although surely there are others. These four areas include:

1) Complexity and Dynamics at the Socio/Technical/Wildlands Interface: The rapid series of events illustrated by the timeline shown in Figure 1 demonstrate the complex interactions among the terrain, winds, temperature, and forest that created a natural environment highly susceptible to fire in Butte County. Add to the fragile natural environment a flawed technical system that has the capacity to ignite flames, and the risk grows. Mobilize resources over long distances in a rural region, and the time required for travel limits immediate action. The ignition escalates until it reaches a threshold point that defies human intervention with every minute of delay. The fire then feeds itself, and enters a transition phase that consumes any natural, technical, or human phenomena in its path [15]. This ignition pattern and escalation of wildfire in social and human environments are not new [16]-[18]. What is new is the capacity to bring together a range of knowledge, skills, technologies, and disciplines to create a shared base of knowledge for all organizations, jurisdictions, and actors involved in this process [19].

While planning for organizational and community response is essential, the complexity of this environment requires a deeper knowledge of the science underlying the hazard of wildfire, recognition of the interactive consequences of the changing environment, and adoption of innovative technologies to monitor and model changes in the underlying conditions that precipitate wildfire [20]. Further, both evolving knowledge and technologies support an iterative process of review, reflection, and redesign for the organizational programs designed to engage residents at the wildland interface in adapting their actions to the changing environment.

Public agencies have the legal responsibility to lead this task, but they cannot do it alone. Actions are taken in response to fire ignition build on the degree of preparedness, organizational capacity, technical infrastructure, knowledge, and training before the fire breaks out. Building resilience to wildfire requires the full commitment of all organizations and jurisdictions, business entities, community groups, and households to monitor the risk and adapt their actions accordingly. Understanding the depth and complexity of wildfire risk in a changing socio/technical/ecological environment is the first step toward managing this risk more effectively.

2) Communications: As the timeline in Figure 1 shows, communication among multiple agencies, jurisdictions, and communities at risk is fundamental to alerting communities to 
danger and mobilizing response operations rapidly. The basic communications infrastructure available to emergency personnel in California is effective for managing routine, daily emergencies. In urgent, catastrophic events as in wildfire, when the technical infrastructure that supports the state-wide 911 system is also under threat, the communications system, by definition, is vulnerable. Without communications, the capacity to mobilize coordinated interorganizational, inter-jurisdictional response operations drops. The loss of cell towers as the fire advanced in Paradise sharply reduced communications as town residents faced the most urgent evacuation tasks. The planned roll-over of 911 dispatch calls from Paradise to Chico to Butte County facilitated the region-wide communications process. However, for residents reliant on cell phone access, the loss of communications at the most critical time left them dependent on their own resources, their immediate neighbors, and local personnel.

Further, the volume of calls in such an event escalates tenfold beyond normal operations. For example, Butte County Dispatch reported 2800 calls logged on November 8, 2018, by midnight; 1400 incidents were created in all call areas of the County. For the period, November 8-30, 2018, Butte County Dispatch logged over 30,000 phone calls. One dispatcher had 563 calls in a 12-hour shift, or approximately 47 calls per hour (Professional interview, Oroville, CA, 3/26/2019). This volume of activity places extraordinary mental and emotional demands on the dispatchers who create a vital human connection between the changing dynamics of the fire and the callers seeking assistance.

Communications is fundamentally a sociotechnical process that enables humans to engage in informed, coordinated actions [21]. In a catastrophic event like the Camp Fire, the limitations of the technical infrastructure, hardware, and software that enable humans to exchange information over distance in timely mode quickly become apparent under the stress of the actual event. The functionality of the communications system is a measure of performance for the overall response system. Yet, communications within the larger response system are composed of multiple interaction points- hardware to software, software to human operator, human operator to sender and receiver. Each of these points comes under stress in an extreme event, and the capacity of the communications system to maintain its interdependent functions depends on workable connections among all points. If any one point fails, the communications system falters.

Extreme events become testing grounds for communications systems, and response operations in the Camp Fire provided a rigorous test. Cal Fire, the state fire protection agency, had primary responsibility for managing operations in this event, but established a collaborative working relationship with relevant state agencies through the State Operations Center activated by the California Office of Emergency Services. Other state agencies mobilized for response operations included the California Highway Patrol, California Department of Fish and Wildlife, California Department of Justice, California National Guard, and California Department of Health and Human Services. Cal Fire uses a radio system that has a common platform with law enforcement and emergency medical services, agencies that serve as first responders in urgent events. The capacity for cross-agency communication is critical in a fast-moving event, but it also has the disadvantage that in intense activity, if too many personnel try to use the system simultaneously, the resulting chatter blocks communication for anyone.

In the Camp Fire, public agencies used any and all modes of communication to alert residents to danger: radio, cell phone, internet, social media platforms such as Facebook and Twitter. The Paradise Police Department sent two Code Red messages to all residents via landlines, alerting them to the fire and ordering a mandatory evacuation of the town. The national emergency alert systems - Wireless Emergency Alert (WEA) and Integrated Public Alert and Warning System (IPAWS) - were not used as both systems require internet access and broadband spectrum that were not available. Throughout Butte County, residents exchanged messages via social media to send and share updates on the changing situation when cell phones failed, or radio systems were not available.

The mix of communications systems revealed breaks in the available networks that warrant review. Importantly, the California Highway Patrol (CHP) does not share a common platform with Cal Fire and local law enforcement agencies, such as the Butte County Sheriff's Office or Chico Police. This was a critical break in the process, as law enforcement agencies were managing the evacuation of the Town of Paradise and other small communities. Other breaks already noted included the collapse of cell phone communication in Paradise and parts of Chico and the transfer of 911 dispatch services from Paradise to Chico to Butte County.

3) Evacuation: As already noted, evacuation became the only strategy possible for the Town of Paradise and other small communities in Butte County, given the rapid escalation of the wildfire. Yet, the actual evacuation was constrained by the physical network of roads, the limited time available for residents to leave safely, and the number of people and vehicles that could move through the available routes. Evacuation is primarily the responsibility of law enforcement, and the local police departments of Paradise and Chico and the Butte County Sheriff's Office were actively engaged in initiating the process. In this event, the intensity of the fire demanded that all emergency personnel support evacuation, so fire and emergency medical personnel worked directly with police to assist local residents. Local residents also joined this effort. A newly elected Town Council member directed traffic at intersections; residents with extra space in their vehicles offered rides to neighbors who needed assistance. In one particularly critical situation, approximately 200-300 residents were stranded in Paradise, unable to leave, with the fire advancing around them. Local fire personnel directed the group to the Walgreen's drug store, recently built with fire-resistant construction, and ushered the whole group into the building to shelter in place. Outside, fire personnel circled the building with their engines to protect it. Inside the building, personnel took fire extinguishers off the shelves and used them to cool the building and protect the people inside (Professional interview, February 12, 2019). Such decisions were not written in any emergency plan but were made by quick-thinking first responders who recognized the risk, searched for available resources, and took prompt action to protect the residents of the town. 
4) Self-Organization in the Community: Throughout the intense activities of this extreme event, there is a remarkable demonstration of translating cognition of risk into shared action for the benefit of the community [22]. Emergency personnel demonstrated extraordinary courage in risking their own lives to protect residents of the community. Public personnel worked long hours under intensely demanding conditions to provide the best services possible. Local leaders set the example for informed, collaborative action to protect the community. Ordinary residents understood that message, and translated it into action in their own ways, helping one another, staying calm, and focusing on the primary goal: enabling the entire community to evacuate safely.

In many respects, this capacity for self-organization under threat is the goal of community resilience. In the case of the Town of Paradise and Butte County, several factors likely contributed to its development. The Town of Paradise, Butte County, and the State of California had undertaken the active planning processes prior to the fire that contributed significantly to creating an informed understanding of the risk of wildfire in the community. Prior experience with wildfire in Butte County in 2008 and in adjacent counties likely led to increased awareness of residents regarding the vulnerability of the region. The recent experience of evacuation from the threat of collapse of the Oroville Dam created a practice scenario for evacuation in extreme events for public personnel. Local law enforcement personnel referenced this event several times as a learning experience regarding the complexity of interactions for multijurisdictional events and the coordination required to carry them out successfully. Active engagement by local leaders who understood the physical and technical characteristics of the region, and the limitations these characteristics imposed upon formal plans reinforced a vision of responsible leadership that enabled personnel in the field to take timely, informed action based on direct observation of risk and the resources available.

The events documented in the Camp Fire demonstrate vividly that self-organization indeed occurred in the Town of Paradise and surrounding jurisdictions. The capacity to recognize risk and translate that cognition into collective action under existing conditions is the goal of a resilient community [23]. It is also the area where research and modeling may offer possible strategies to assist communities in building that capacity. As part of this study, our research team developed a simulation of traffic patterns in the region to explore possible alternatives for evacuation in future events or in other communities that confront similar physical/ecological/meteorological risks.

\section{Paradise Traffic Simulation}

In an effort to understand the cascading effects of the Paradise Camp Fire, a countywide traffic simulation was performed to identify network vulnerabilities due to limitations in road capacity. For the purpose of this analysis, the traffic simulation is carried out by modeling a set of vehicles that find each vehicle's instantaneous, fastest path to evacuate in a transportation network [24]. The advantages of this study's framework over many of the commercially available traffic simulation tools are flexibility, performance, and the evacuation-specific nature of the model. This temporo-spatial parallel computing tool can simulate regional-scale infrastructure networks with hundreds of thousands of links and millions of trips traveling in near real time [25].

The framework for the traffic simulation can be summed up in three main steps shown in Figure 3. In the first step (road network generation), the road network is generated based on data from the OpenStreetMap (OSM), an open-source editable map of the world using volunteered geographic information. The entire Butte County Road network can be downloaded from the OSM by querying the data within the bounding box [39.361, -122.431, 40.071, -120.981]. A graph object is then created based on the downloaded data for shortest path calculations in the later stage of the traffic simulation. Butte County's Road network consists of 31,653 vertices (road intersections in graph terminology) and 75,559 edges (road links between two intersections). In addition to the vertices and edges, the OSM data also include attribute information, such as road types, lane counts, and speed limits for each road link. Capacity for each road can then be determined based on the attribute information. During step two (travel demand modeling), an hourly Origin Destination (OD) matrix is constructed for the assumed travel demand. Most commonly, the travel demand is informed by the survey data, such as the California Household Travel Survey (CHTS) or the Census Transportation Planning Package (CTPP) [26]. Due to the limited time for this case study, intracity and intercity travel demands are constructed simplistically according to the population in each municipality in the Butte County. Table 1 lists the numbers of trips for the five largest municipalities (Chico, Paradise, Oroville, Oroville East, and Magalia) and the remainder of Butte County in the base scenario (i.e., no evacuation). These trips do not necessarily represent peak hour travel demand on a specific weekday; however, it is acceptable for testing regional scale modeling. Finally, in step three, shortest path calculations for each OD pair are completed using Dijkstra's Algorithm. Volume-delay curves are incorporated in the simulation to model the impact of increased congestions and delays on road links given their fixed capacities. Further details of the model can be found from the open source GitHub repository: https://github.com/cb-cities/sf_abm for San Francisco.

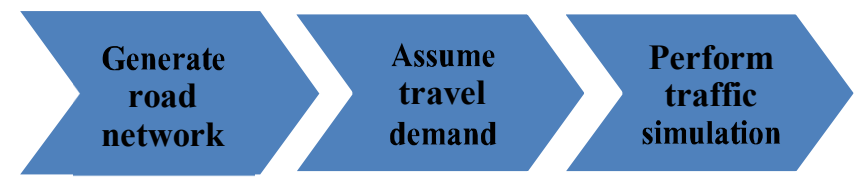

Fig. 3 Framework of the traffic simulation steps

The traffic simulation experiment design consists of two scenarios. The first is the base scenario that represents the ordinary day peak hour traffic in the study area, that is, no evacuation is considered. The second is the evacuation scenario where all residents in the wildfire-affected municipalities (Paradise and Magalia) seek to evacuate to nearby towns (Chico, Oroville and Oroville East). For the base scenario, 14,293 trips $(10 \%$ of all vehicles in the Butte County, disaggregated to municipalities as shown in the last column in Table 1) are simulated to represent the peak hour traffic across Butte County. The maximum link volume is 1,592 vehicles over a one- hour time step as in Figure 4. 


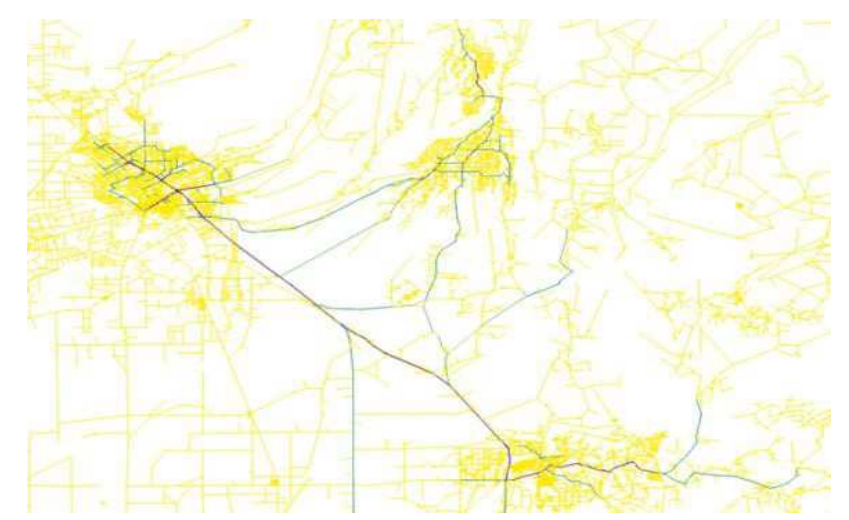

(a)

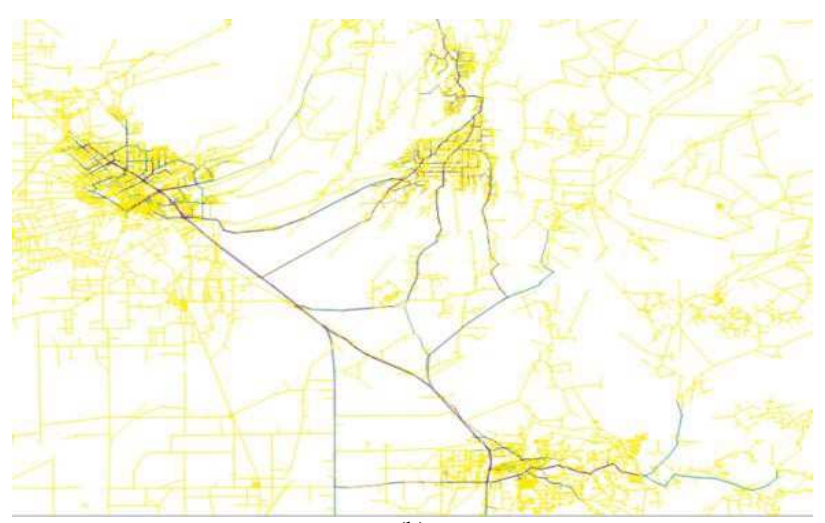

(b)

14,293 trips (Assumed Peak Hour Travel) 39,630 trips (Evacuation and background traffic) Maximum link volume: 15,92

Fig. 4 Traffic volume distributions on the Butte County Road network. (a): Base scenario, normal peak hour traffic and no evacuation. (b): Evacuation scenario (evacuation vehicle trips from Paradise and Magalia, plus normal peak hour traffic in other parts of the Butte County).

Figure 4(a) shows the resulting link volume or number of vehicles per link with yellow links representing little to no traffic and darker green links representing high volume roads. For the Town of Paradise, Skyway Road, Neal Road, and Clark Road are identified as high-volume links connecting Paradise to Chico, Oroville, and the rest of Butte County.

In the evacuation scenario, additional traffic is considered due to the evacuation of Paradise and Magalia residents. The total travel demand of the evacuation scenario equals to 39,360 trips, including 28,151 vehicle trips representing the evacuation of 26,218 Paradise residents and 11,310 Magalia residents ( $75 \%$ car ownership is assumed), as well as 11,479 non-evacuation vehicle trips in other areas of the network. This represents an additional 25,337 vehicles traveling on the network compared to the base scenario. The 28,151 vehicles originating from Paradise and Magalia are split with $33.3 \%$ of trips to Oroville, and the remaining $66.7 \%$ of trips to Chico. The new maximum link volume is 19,631 vehicles, which represents an increase of more than 6 times the original maximum link volume under the base scenario. Figure 4(b) shows the link volume results for the Paradise evacuation scenario. One feature worth highlighting is the shift in traffic on previous high link roads like Neal Road to Skyway Road and the importance of Highways 99 and 149 in the evacuation.

These simulations are not intended to reenact exact conditions for peak hour travel or the Camp Fire specifically; however, they do aim at offering insights into potential bottlenecks and the impact of evacuation on surrounding communities. The results underscore the importance of communication, especially across city boundaries. Future simulations will be aimed at the impact of contraflow on evacuation as well as closing certain roads, such as Pentz Road, on affecting route choice and travel time on the day of evacuation. Additionally, modeling traffic buildup in Chico as a result of limited communication between Paradise and Chico on traffic congestion is also of interest. Implementing contraflow will offer insights on the minimum amount of time needed to evacuate Paradise under ideal conditions. Additionally, by overlaying fire intensity on time and the transportation network, it is possible to create a more realistic evacuation due to closed roads for the Camp Fire scenario. The flexibility, speed, and simplicity of this traffic model are very useful in a variety of applications and are tailored towards understanding regional scale implications of various travel scenarios.

TABLE I

Population, Assumed CAR OWNERShip AND PEAK HOUR TRAVEL DEMAND IN BUTTE COUNTY MUNICIPALITIES

\begin{tabular}{cccc}
\multicolumn{4}{c}{ DEMAND IN BUTTE COUNTY MUNICIPALITIES } \\
\hline Chicipality & Population & $\begin{array}{c}\text { Number of } \\
\text { Vehicles** }\end{array}$ & $\begin{array}{c}\text { Peak Hour } \\
\text { Trips }^{* * *}\end{array}$ \\
\hline Paradise & 86,187 & 64,594 & 6,459 \\
Oroville & 15,218 & 19,668 & 1,966 \\
Magalia & 11,310 & 11,544 & 1,154 \\
Oroville East & 8,280 & 8,483 & 848 \\
Rest of Butte & 43,336 & 6,199 & 619 \\
County* & 32,473 & 3,247 \\
Total & 190,877 & 142,961 & 14,293 \\
\hline * Total
\end{tabular}

* Total Butte County Population of 190,877 based on 2010 American Community Survey (ACS).

** ACS data for single vehicle ownership for Butte County (75\%).

*** Assumed $10 \%$ of all the vehicles are traveling during peak hour.

\section{E. Renewal, Recovery, and Redesign}

The traffic simulation offers an innovative approach to rethinking the design, construction, and management of traffic on a regional scale for the Town of Paradise. Other types of modeling may be productive to explore the most costeffective means of rebuilding major infrastructure for the damaged community. There are serious reasons to question whether the fragile location of the town warrants rebuilding. The interdependent consequences of the wildfire are still unfolding. For example, seven months after the fire, there was still no piped water in the Town of Paradise. The fire's intense heat damaged the fragile water infrastructure, as it warped the shallow PVC (polyvinyl chloride) piping that provided water to the town. Chosen for its flexibility, low cost, and resilience during seismic events, PVC piping had the opposite effect in wildfire. The PVC infrastructure, although buried underground, failed under the intense heat and leached chemicals into the water flowing through the pipes, contaminating the water, making it undrinkable and thereby creating a secondary disaster. The cost of replacing the entire water infrastructure for the Town of Paradise has been estimated at $\$ 500,000,000$, an enormous sum for a small community. Further, since the Paradise Irrigation District that 
manages the water system for the town is a private company, this cost is not eligible for federal reimbursement under the Stafford Act, which provides reimbursement for public infrastructure. Yet, rebuilding the water infrastructure for the town is essential for all other aspects of recovery: homes, businesses, schools, hospital services are all dependent upon ready access to water. The major question is how, when, and whether this process could be undertaken. For many residents of Paradise, the goal of rebuilding is not in question. Rather, exploring alternative strategies for reconstruction and finance through modeling and creating a wider range of access to resources and knowledge to support this effort becomes essential to the recovery process.

\section{CONCLUSION}

Reviewing the conditions, operations, and consequences that characterized this devastating event, five conclusions can be drawn in reference to mitigating the risk of wildfire in other communities.

\section{A. Changing Wildfire Risk Requires Adaptation in Budget and Capacity for Collective Action}

The events of the Camp Fire documented in unambiguous detail the effects of a changing climate on the forest and grasslands of Butte County, with increasing risk of wildfire to the built environment and communities of the region. The need for increased monitoring of sensitive conditions such as temperature, flammability of ground cover, technical infrastructure for communications, water, and power all require public investment in the science and technology of managing wildfire risk. While public agencies have the legal responsibility to lead this effort, effective risk reduction will require the collaborative effort of private companies, research institutions, and nonprofit organizations as well. For states like California, Arizona, Colorado, Oregon, and Washington, building collaborative models of risk reduction and dynamic operations that scale to changing exposure would be an invaluable investment in collective capacity to manage wildfire risk. Such effort will be expensive, but far less expensive than the billion-dollar costs that are likely to ensue if no action is taken.

\section{B. Cognition to Action-Informed Residents of Communities at Risk Will Take Responsible Action to Protect the Community as a Whole}

A major resource for communities exposed to wildfire risk is an informed, responsible population. The actions taken by ordinary residents of Paradise and surrounding communities demonstrated the capacity of local residents unequivocally to take informed action to protect themselves, their neighbors, and their community facilities. Investment in programs of public education regarding wildfire risk, voluntary training, and access to multiple modes of communication enable community residents to build a degree of shared knowledge to recognize risk and act collectively to reduce risk for the community.

\section{Learning from Prior Experience}

Translating insights gained in other, relevant, large-scale, complex events for application to wildfire risk reduction increases the capacity of community organizations to act in coordinated effort to reduce shared risk. Several interviewees in this study referenced the experience of the Oroville Dam evacuation as a constructive rehearsal for the coordination needed in a large-scale evacuation effort as required for the Town of Paradise and surrounding communities.

D. The intersection of Science, Technology, and Human Organizations Creates a New, Interdisciplinary Science for Managing Wildfire

The rapidly changing, dynamic conditions that propelled the Camp Fire to its full, destructive impact in Butte County in November 2018 demonstrated decisively that no single discipline, no single organization could anticipate or manage to contain such a wildfire alone. It was the intersection of drought conditions, high winds, topography, and a faulty technical system that drove the fire, but a limited road network accelerated these conditions for the region, limited equipment and trained personnel, and repeated disruptions in communications that inhibited coordination among organizations and people. To overcome these constraints, it is essential to reconsider the hazard of wildfire as generating a complex system of interacting systems that can learn and adapt to rapidly changing risk conditions.

\section{E. Need for Innovative Approaches, New Technologies, Organizational Designs, and Science}

This study of the Camp Fire has demonstrated that a detailed command of the science underlying forest and grasslands management, well-designed sensors to detect change in ecological conditions, systematic data collection and analysis of both technical and organizational capacity, regular monitoring of changing conditions, and innovative modeling are essential to anticipate potential strategies for managing the known risk wildfire that generates unknown consequences for communities at risk. Building the capacity to anticipate and reduce the cost of wildfire to urban communities will require steady, consistent leadership and effort in confronting markedly changing firescapes.

To a significant extent, this process has already started in California. The proposed plan of Governor Newsom for public investment in wildfire risk reduction and planning [3] addresses this need directly. Engaging the scientific and technical resources of the ten campuses of the University of California would be a beginning step in building the knowledge base for a state-wide map of wildfire risk and resources. Nevertheless, such a process would require continuing research, community engagement, and collective action across the state, a bold but important step to reduce wildfire risk.

\section{ACKNOWLEDGMENTS}

With thanks and appreciation, we acknowledge the participation of Mark Stacey and Jillian Dressler in field trips for this study. The study has been conducted with support from the Quick Response Program administered by the Natural Hazards Center, University of Colorado, Boulder, for the National Science Foundation. With thanks and appreciation, we acknowledge the staff of the Natural Hazards Center in facilitating this study. We further give warm thanks and appreciation to the public officials and staff from the following organizations who gave their time and shared their 
experience with us: Cal Fire; California Office of Emergency Services; Unit 35, Fire Department, Butte County; Police Department, Public Works Department, and Mayor, Town of Paradise; 911 Dispatch Office; Sheriff's Office and Fire Department, Butte County; City of Chico Police Department; Federal Emergency Management Agency, Individual Assistance Program and Small Business Administration. These officials are not named to protect their confidentiality, but we are grateful for their thoughtful insights into the very dynamic, complex problem of wildfire risk reduction.

\section{REFERENCES}

[1] NBC NEWS, "California wildfires costs soar past last year's records." https://www.nbcnews.com/news/us-news/california-wildfires-costssoar-past-last-year-s-records-n946856 (accessed Jun. 09, 2021).

[2] K. Pierre-Louis, "These Billion-Dollar Natural Disasters Set a U.S. Record in 2017 - The New York Times," The New York Times. https://www.nytimes.com/2018/01/08/climate/2017-weatherdisasters.html (accessed Jun. 09, 2021).

[3] Governor Newsom's Strike Force, "Wildfires and Climate Change: California's Energy Future," 2019.

[4] R. K. Yin, Case Study Research and Applications: Design and Methods. SAGE Publications, 2017.

[5] L. Comfort et al., "Collective Action in Communities Exposed to Recurring Hazards: The Camp Fire, Butte County, California, November 8, 2018," Boulder, USA Univ. Color. Nat. Hazards Cent., 2019.

[6] Federal Emergency Management Agency, "National Planning Frameworks," Framework for Each Mission Area, 2020. https://www.fema.gov/emergency-managers/national-

preparedness/frameworks (accessed Jun. 09, 2021).

[7] S. L. Cutter, "The changing context of hazard extremes: Events, impacts, and consequences," J. Extrem. Events, vol. 3, no. 02, p. $1671005,2016$.

[8] S. L. Cutter, "The Changing Nature of Hazard and Disaster Risk in the Anthropocene," Ann. Am. Assoc. Geogr., vol. 111, no. 3, pp. 819-827, Apr. 2021, doi: 10.1080/24694452.2020.1744423.

[9] California Emergency Management Agency, "Regulations Standardized Emergency Management Systems (SEMS)," State of California,

2010 https://www.caloes.ca.gov/PlanningPreparednessSite/Documents/SE MS Regulations.pdf.

[10] California Department of Forestry and Fire Protection (Cal Fire), "2018 Strategic Fire Plan for California," Butte County Community $\begin{array}{lll}\text { Wildfire Protection } & \text { Plan, } & \end{array}$ https://buttecounty.sacriver.org/object/8351 (accessed Jun. 09, 2021).

[11] C. Dwyer, "Verizon Throttled Firefighters' Data As Mendocino Wildfire Raged, Fire Chief Says : NPR," National Public Radio, 2018. https://www.npr.org/2018/08/22/640815074/verizon-throttledfirefighters-data-as-mendocino-wildfire-raged-fire-chief-says (accessed Jun. 09, 2021).
[12] J. Serna and T. Luna, "PG\&E power lines caused California's deadliest fire, investigators conclude - Los Angeles Times," Los Angeles Times, 2019. https://www.latimes.com/local/lanow/la-meparadise-camp-fire-cal-fire-20190515-story.html (accessed Jun. 09, 2021).

[13] L. K. Comfort, The Dynamics of Risk: Changing Technologies and Collective Action in Seismic Events. Princeton University Press, 2019.

[14] T. W. Collins, "Households, forests, and fire hazard vulnerability in the American West: A case study of a California community," Environ. Hazards, vol. 6, no. 1, pp. 23-37, Jan. 2005, doi: 10.1016/j.hazards.2004.12.003.

[15] M. A. Finney et al., "Role of buoyant flame dynamics in wildfire spread," Proc. Natl. Acad. Sci., vol. 112, no. 32, pp. 9833-9838, Aug. 2015, doi: 10.1073/pnas.1504498112.

[16] T. J. Cova and J. P. Johnson, "Microsimulation of Neighborhood Evacuations in the Urban-Wildland Interface," Environ. Plan. A Econ. Sp., vol. 34, no. 12, pp. 2211-2229, Dec. 2002, doi: 10.1068/a34251.

[17] K. Hardy and L. K. Comfort, "Dynamic decision processes in complex, high-risk operations: The Yarnell Hill Fire, June 30, 2013," Saf. Sci., vol. 71, pp. 39-47, Jan. 2015, doi: 10.1016/j.ssci.2014.04.019.

[18] I. Altintas et al., "Towards an Integrated Cyberinfrastructure for Scalable Data-driven Monitoring, Dynamic Prediction and Resilience of Wildfires," Procedia Computer Science, 2015. https://linkinghub.elsevier.com/retrieve/pii/S1877050915011047.

[19] J. L. Coen, W. Schroeder, S. Conway, and L. Tarnay, "Computational modeling of extreme wildland fire events: A synthesis of scientific understanding with applications to forecasting, land management, and firefighter safety," J. Comput. Sci., vol. 45, p. 101152, Sep. 2020, doi: 10.1016/j.jocs.2020.101152.

[20] B. Nowell and J. Stutler, "Public Management in an Era of the Unprecedented: Dominant Institutional Logics as a Barrier to Organizational Sensemaking," Perspect. Public Manag. Gov., vol. 3, no. 2, pp. 125-139, Jun. 2020, doi: 10.1093/ppmgov/gvz028.

[21] N. Wiener, Cybernetics or Control and Communication in the Animal and the Machine. MIT press, 2019.

[22] L. K. Comfort, N. Kapucu, K. Ko, S. Menoni, and M. Siciliano, "Crisis Decision-Making on a Global Scale: Transition from Cognition to Collective Action under Threat of COVID-19," Public Adm. Rev., vol. 80, no. 4, pp. 616-622, 2020.

[23] L. K. Comfort, "Crisis Management in Hindsight: Cognition, Communication, Coordination, and Control," Public Adm. Rev., vol. 67, pp. 189-197, Dec. 2007, doi: 10.1111/j.1540-6210.2007.00827.x.

[24] G. Casey, K. Soga, E. Silva, P. Guthrie, and K. Kumar, "A scalable agent based multi-modal modeling framework using real-time big-data sources for cities," 2017.

[25] M. McElwee, B. Zhao, and K. Soga, "Real-time Analysis of City Scale Transportation Networks in New Orleans Metropolitan Area using an Agent Based Model Approach," in MATEC Web of Conferences, 2019, vol. 271 , p. 6007.

[26] J. H. Seo, T. Vo, S. Lee, F. Wen, and S. Choi, "The CTPP Workplace Data for Transportation Planning: A Systematic Review," 2017. 


\section{APPENDIX A}

Cooperating Agencies in Response Operations, November 8, 2018 :

The following agencies were listed by Cal Fire as cooperating in the response operations to the Camp Fire, November 8, 2018:

California Department of Transportation

California Department of Corrections and Rehabilitation California Highway Patrol

California Office of Emergency Services

National Weather Service, California Conservation Corps Butte County City of Chico.

Agencies Responding to Requests for Comments, Recommendations, Strike Force Report, April 12, 2019:

The following agencies, departments, regional and local government entities, and non-governmental partners responded to CAL FIRE's request for comments and recommendations on draft copies of Governor Newsom's Strike Force report in writing or through conversation, March-April, 2019.

Governor's Office of Emergency Services Governor's Office of Planning and Research

California Natural Resources Agency Strategic Growth Council Office of State Fire Marshal

California Air Resources Board

California Department of State Parks California Department of Fish and Wildlife California Department of Public Health California Energy Commission

California Public Utilities Commission California Department of Transportation California Department of Industrial Relations

Sierra Nevada Conservancy University of California Berkeley University of California Cooperative Extension (UCANR) Humboldt State University

California Forest Management Task Force US Forest Service PSW Research Station Natural Resources Conservation Service

North Coast Regional Water Quality Control Board Central Valley Regional Water Quality Control Board Lahontan Regional Water Quality Control Board

Los Angeles Regional Water Quality Control Board

California Fire Chief's Association California Environmental Justice Alliance Morongo Fire District The Nature Conservancy Resources Legacy Fund Pacific Forest Trust California League of Cities California Fire Safe Council The Red Cross

California Licensed Foresters Association Sierra Forest Legacy Trinity County Fire Safe Council

Lower Mattole Fire Safe Council and Mattole Restoration Council Watershed Research and Training Center ForEverGreen Forestry The Fire Restoration Group
Mendocino/Humboldt Redwood Company

Green Diamond Resource Company Sierra Pacific Industries California Cattlemen's Association Town of Portola Valley

\section{APPENDIX B}

Field Activities, Camp Fire Study, January - March 2019. Study Team, University of California, Berkeley:

Three faculty: Kenichi Soga, Civil and Environmental Engineering; Louise Comfort, CITRIS, Mark Stacey, Civil and Environmental Engineering. Four graduate students: Millard McElwee, Jillian Dressler, Bingyu Zhou, Civil and Environmental Engineering; Chiara Ecosse, Architecture

Six field trips; 11 interviews conducted for study: additional meetings attended in reference to study.

Trip \#1: January 15, 2019, Sacramento, CA. Interviews:

California Office of Emergency Services. Two personnel: Operations Chief; Branch Manager, CA 911 Emergency Communications, Cal Fire: Deputy Director, Communications.

Trip \#2: February 12, 2019. Town of Paradise. Interviews: Cal Fire, Butte County Unit 35, Town of Paradise. Paradise Police Department.

Trip \#3: February 21, 2019. Town of Paradise. Interviews: Public Works Department, Town of Paradise Mayor, Town of Paradise

Trip \#4: March 12, 2019, Sacramento, CA. Joint Interview: Joint Federal/State Disaster Field Office FEMA and Cal OES staff; four personnel; two programs: Individual Assistance; Small Business Administration

Trip \#5: March 26, 2019, Butte County, Cities of Oroville and Chico. Interviews:

911 Dispatch Center, Butte County Sheriff's Office, Oroville, CA Chico Police Department, City of Chico. Four personnel.

Office of the Sheriff, Butte County, Oroville, CA

Fire Department, Butte County Oroville, CA

Trip \#6: March 17, 2019. Reconnaissance Trip, Jarbo Gap Meetings attended; visits made:

February 12, 2019. Disaster Recovery Center, Public Information Officer, FEMA.

February 12, 2019. Town Council Meeting, Town of Paradise, Town Hall. 6:00 p.m. Speakers: Department of Employment and Social Services, Butte County

Paradise Unified School District Small Business Administration Comcast

Paradise Irrigation District 